\title{
FUNGICIDAL ACTIVITY OF NANOEMULSIFIED ESSENTIAL OILS AGAINST BOTRYTIS LEAF BLIGHT OF POINSETTIA (EUPHORBIA PULCHERRIMA) IN EGYPT
}

\author{
HASSANIN, M. M. H. ${ }^{1}$, NAGLAA T. MOHAMED ${ }^{1}$ and M.A. ABD-EL-SAYED ${ }^{2}$
}

1. Plant Pathology Research Institute, Agric. Res. Center, Giza, Egypt.

2. Horticulture Research Institute, Agricultural Research Center (ARC), Giza, Egypt.

(Manuscript received 3 July 2018)

\begin{abstract}
$\mathrm{B}$ otrytis blight was observed in Egypt (Nov., 2016) on Poinsettia (Euphorbia pulcherrima) that caused small light brown spots at the edge of leaves and enlarged to include the whole leaf. The isolated fungus was identified as Botrytis cinerea based on its morphological and cultural characteristics. In greenhouse, artificial inoculation of plants developed blight symptoms. The effect of ultrasonication on the particle size of lemongrass and citronella essential oil nanoemulsions was determined. The results showed that the particle sizes from sonication for 30 minutes were around 90.6 and $79.8 \mathrm{~nm}$, and TEM study revealed the spherical shape. Changes in the essential oil emulsions components were observed in the nanoemulsions compared with the original as the size of the oil particles become small, the stability and main component of the emulsion were significantly improved. In vitro, the nanoemulsion at different concentrations (1000 - 8000 ppm) were capable of adversely affecting the mycelial growth of Botrytis cinerea. In greenhouse experiment, poinsettia plants were sprayed with the two essential oils (emulsion and nanoemulsion) and the fungicide carbendazim $50 \%$ WP (as additional control), after and before inoculation by the fungus. The disease severity was decreased by the treatments compared to the untreated control. The lowest disease severity, being 10.0 and $13.0 \%$ with nanoemulsion of lemongrass, before and after inoculation by the fungus, respectively. The results indicate an increase in the concentrations of active substances in essential oils due to their exposure to ultrasonication and their conversion to nanoemulsions, as the results suggest the potential effects of lemongrass essential oil nanoemulsion as a novel fungicide agent against Botrytis cinerea.
\end{abstract}

\section{INTRODUCTION}

Poinsettia (Euphorbia pulcherrima Willd. ex. Klotzsch) is flowering potted shrubs belongs to the Euphorbiaceae family and is highly sensitive to photoperiod and temperature (Larson et al., 1978). Though the flowers are small and not attractive, the colorful bracts (top leaves) that are present around the flowers in the centre make the plant attractive. Its cultivation in Egypt has started since 1860 (Anonymous, 2011).

Poinsettias are suffering over the growing season from different diseases (Margery Daughtrey and Chase, 2016). One of the destructive diseases of poinsettias 
worldwide being the Botrytis blight caused by Botrytis cinerea (Pritchard et al., 1996 and Margery Daughtrey et al., 2000). Tan to brown lesions form on leaves, stems, and bracts. Extensive tan cankers can form on stems when $B$. cinerea enters via blighted petioles or shoots. Lesions begin at the margins of bracts, turning darker as they expand (Margery Daughtrey et al., 2000).

The control of this pathogen is still based upon multiple applications of fungicides. Chemical control is effective and efficient but, at the same time, can lead to the development of pathogen resistance, phytotoxicity to other organisms or environmental and public health problems (Brent and Hollomon, 1998 and Adebayo et al., 2013).

In order to minimize the deleterious effect, there exist an accumulative interest in bio-ecology studies of this pathogen and a worldwide trend to explore new alternatives to synthetic fungicides. Among alternative methods, the use of natural compounds as essential oils is one which can be characterized by less toxicity for humans and environment safety, selectivity, biodegradable liability and a variety of chemical secondary metabolites. Essential oils as well as compounds derived from them possess wide range of antimicrobial activities (Hammer et al., 2003 and Pepeljnjak et al., 2003). One of the potent antimicrobial compounds isolated from essential oils are lipophilic monoterpens such as thymol, carvacrol, linalool, citral, geraniol and 1,8cineole. Their applications as preservatives in food or antiseptics and disinfectants were widely studied (Pauli, 2001 and Burt, 2004). Essential oil nanoemulsions are preferred due to higher solubilization capacity and thermodynamic stability as compared to unstable emulsions and suspensions (Anton and Vandamme, 2011 and Abd-Elsalam and Khokhlov, 2015).

In this work, Lemongrass and citronella essential oils were selected for the preparation of nanoemulsion of oil in water was formulated using non-ionic surfactants such as Tween 80 by ultrasonic emulsification method. Effect of sonication on droplets size of nanoemulsion and chemical composition was investigated. The antifungal activities of lemongrass and citronella essential oil nanoemulsions were evaluated in vitro and in vivo.

\section{MATERIALS AND METHODS}

\section{Isolation of the pathogen}

Poinsettia plants with typical symptoms of botrytis blight were collected from a nursery located at Qalubiya governorate (Nov., 2016). The leaves were washed with tap water, cut into reasonable pieces, surface sterilized by immersing in $2 \%$ sodium hypochlorite for $2 \mathrm{~min}$, washed in several changes of sterile water, transferred to plates of potato dextrose agar (PDA) and incubated at $20 \pm 1^{\circ} \mathrm{Cfor} 7$ days. The growing fungi 
were purified and identified according to their morphological and cultural characteristics as mentioned by Palmucci and Grijalba (2005).

\section{Pathogenicity :}

The pathogenicity test was carried out in the greenhouse on 10 plants using a spore suspension of the tested fungus. A spore suspension was prepared by adding 10 $\mathrm{ml}$ of distilled water to each plate and tapering the spore gently using a camel hair brush. The spores suspension was filtered through two layers of cheesecloth into a sterile flask, and the concentration was adjusted to $\left(2 \times 10^{6} \mathrm{spores} / \mathrm{ml}\right)$, using a hemocytometer slide. Then Tween 20 (ca. $0.02 \%$ v/v) was added, as a wetting agent, and used immediately.

The spore suspension was sprayed on both leaf surfaces of the plant with an atomizer. Immediately after inoculation, all plants were kept at high humidity in polyethylene bags for 24 hours. Control plants were similarly treated with sterile distilled water.

The severity of poinsettia leaf blight was assessed using (1-10) scale suggested by Mary Hausbeck and Harlan (2011).Grade 1=healthy, $2=$ small isolated lesions, $3=$ moderate-sized isolated lesions, 4=numerous moderate-sized lesions, 5=large necrotic areas, $6=$ large necrotic areas with $30-50 \%$ defoliation, $7=$ large necrotic areas with $51-70 \%$ defoliation, $8=$ large necrotic areas with $71-90 \%$ defoliation, $9=>91 \%$ defoliation, $10=$ plant death. The disease severity equation was as follows:

$$
\text { Disease severity }(\%)=\frac{\sum \mathrm{nxv}}{10 \mathrm{~N}} \mathrm{X} 100
$$

Where: $\mathrm{n}=$ Number of examined leaves in each category. $\mathrm{v}=$ Numerical values of each category. $\mathrm{N}=$ Total number of investigated leaves.

\section{Plant materials}

Fresh herb of lemongrass (Cymbopogon citratus) and citronella (Cymbopogon nardus) were collected at July 2017 from Barrage(El-Kanater El-Khairia) Farm, Medicinal and Aromatic Plants Research Department, Horticulture Research Institute (HRI), ARC, Egypt. Samples from each plant were then shade dried and subject to distillation for essential oil extraction.

\section{Preparation of nanoemulsion:}

Essential oils of air dried herbs of citronella and lemongrass plants were extracted by using steam distillation method (Al-Shahrani et al., 2017). Ten $\mathrm{ml}$ of each essential oil and $5 \mathrm{ml}$ of non-ionic surfactant Tween 80 were added slowly with gentle stirring until a homogeneous mixture formed. Then, water $(85 \mathrm{ml})$ was added to reach the final mixture of each oil to $100 \mathrm{ml}$, then stirred using a magnetic stirrer for $30 \mathrm{~min}$. The mixture was sonicated using an Ultrasonicator (BANDELIN SONOPULS HD 2200, 
Germany) for $30 \mathrm{~min}$. at $700 \mathrm{~W}$, all the treated essential oil were placed in ice bath during the time work. The particle size of $10 \%$ essential oils nanoemulsion for each amount was detected by Hydrodynamic light scattering analyzer (DLS) after 90 days of storage under room temperature $\left(27^{\circ} \mathrm{C}\right)$. Essential oils emulsions were prepared as mentioned above before without sonication.

\section{Measurement of nanoemulsion droplet size:}

Measurement of droplet size of nanoemulsions was performed by a dynamic light scattering analyses using Zeta Nano ZS (Malvern Instruments, UK) at room temperature. Prior to measurement, $30 \mu \mathrm{l}$ of each nanoemulsion were diluted with $3 \mathrm{ml}$ of water at $25{ }^{\circ} \mathrm{C}$. Particle size data were expressed as the mean of the Z-average of 3 independent batches of the nanoemulsions. The droplet size and the poly disparity index (PDI) of the formulated nanoemulsion were measured. This work was performed by Nanotechnology Laboratory, Regional Center for Food \& Feed, ARC, Giza, Egypt according to (Ghotbi et al., 2014).

\section{Transmission electron microscopy (TEM):}

Twenty micro liters of diluted samples were placed on a film-coated 200-mesh copper specimen grid for $10 \mathrm{~min}$ and the excess fluid was eliminated using filter paper. The grid was then stained with one drop of $3 \%$ phosphotungstic acid and allowed to dry for $3 \mathrm{~min}$. The coated grid was dried and examined under the TEM microscope (Tecnai G20, Super twin, double tilt, FEI, The Netherlands), operating at 200 kV.(Saloko et al., 2013).

\section{Essential oil nanoemulsion and analysis}

Essential oils were extracted from the nanoemulsions by redistillation. The Gas chromatography analysis of the essential oil samples was carried out using Ds Chrom 6200 Gas Chromatograph apparatus, fitted with capillary column BPX-5, 5 phenyl (equiv.) polysillphenylene siloxane $30 \times 0.25 \mathrm{~mm}$ ID $\times 0.25 \mu$ film. The temperature program varied in the range of $70^{\circ}-200^{\circ} \mathrm{C}$, at a rate of $10^{\circ} \mathrm{C} / \mathrm{min}$. Flow rates of gases were nitrogen at $1 \mathrm{ml} / \mathrm{min}$, hydrogen at $30 \mathrm{ml} / \mathrm{min}$ and $330 \mathrm{ml} / \mathrm{min}$ for air. Detector and injector temperatures were $300{ }^{\circ} \mathrm{C}$ and $250{ }^{\circ} \mathrm{C}$, respectively (Hamad et al.,2017). This work was performed by Laboratory of Medicinal and Aromatic Plants Research Department, Horticulture Research Institute (HRI), ARC, Egypt.

\section{Effect of essential oils emulsions and nanoemulsions on growth of Botrytis cinerea:}

The efficacy of volatile substances in reducing the fungal growth was tested. Essential oils of citronella and lemongrass (emulsions and nanoemulsions) were added to sterilized PDA flasks before solidifying to obtain the proposed concentrations of 1000 , 
2000, 4000 and 8000 ppm (v/v). The bactericide (Chloramphenicol, $0.1 \mathrm{mg} / \mathrm{l}$ ) was added to the medium to avoid bacterial contamination. Three plates for each treatment were inoculated with discs (5-mm-diam.) of Botrytis cinerea. Petri dishes were incubated at $20 \pm 1^{\circ} \mathrm{C}$. Percentages of fungal growth inhibition were calculated when the fungal growth of the control plates completely filled the plates according to the formula as follows:

$$
\% \text { Inhibition }=\frac{\text { A - B }}{\text { A }}
$$

$A=$ The linear growth in control treatment.

$B=$ The linear growth of treated fungus.

\section{Effect of essential oils emulsions and nanoemulsions on sporulation of Botrytis cinerea:}

Number of spores were counted in both treated and non-treated plates ( 7 days after incubation at $20 \pm 1^{\circ} \mathrm{C}$ ) with oil concentrations of 4000 and $8000 \mathrm{ppm}$. Spores were harvested from margins of the colonies using sterile needle and transferred into the test tubes, each contained $10 \mathrm{ml}$ of sterile distilled water. The tubes were centrifuged at $1000 \mathrm{rpm}$ for 3 minutes to allow for even dispersal of spores. A drop of spore suspension was placed on a haemocytometer slide, then spores were counted in 5 microscopic fields. (Zambonelli et al., 1996)

\section{Effect of essential oils emulsions and nanoemulsions on sclerotial formation of Botrytis cinerea:}

Number of sclerotia were counted in both treated and non-treated plates (21 days after incubation at $20 \pm 1^{\circ} \mathrm{C}$ ) with oil concentrations of 4000 and $8000 \mathrm{ppm}$. Each treatment was replicated three times (Dijst, 1988).

\section{Effect of essential oils emulsions and nanoemulsions on poinsettia leaf blight} caused by $B$. cinerea under greenhouse conditions:

Poinsettia plants were sprayed with the two essential oils (emulsion and nanoemulsion) at rate $(8 \mathrm{ml} / \mathrm{l})$ and carbendazim 50\% WP (Common name: Carbendazim, Chemical composition: 2-(Methoxycarbomylsmino)-benzimidazole) and Manufacture: Agriphar S.A., Belgium. $)(2 \mathrm{~g} / \mathrm{l}) 24 \mathrm{~h}$ after or before inoculation with the fungus), as mentioned before in pathogenicity test to suppress the leaf blight disease. Four plants were used of each treatment.

\section{Statistical analysis:}

The layout of this experiment was designed as factorial experiment in a complete randomized design with three replicates (Snedecor and Cochran, 1989). This 
statistical analysis was done by using the computer program MS-TATEC software version (4) using the L.S.D. test at 0.05 .

\section{RESULTS AND DISCUSSION}

Botrytis cinerea is an ubiquitous fungus, that causes Botrytis blight and occurs wherever poinsettias are grown and causes losses in propagation finishing and postharvest stages. Infections start as small light brown lesions at the edge of leaves and grow into large spots, to include the whole leaf (Fig. 1).The pathogenicity test was carried out on 10 plants and Koch's postulates were applied.

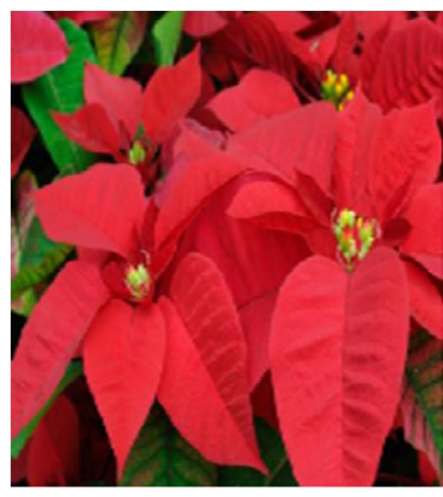

A

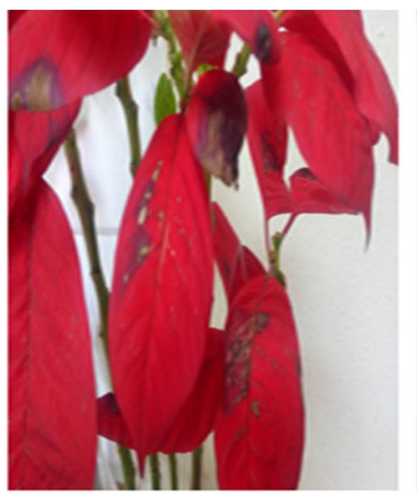

B

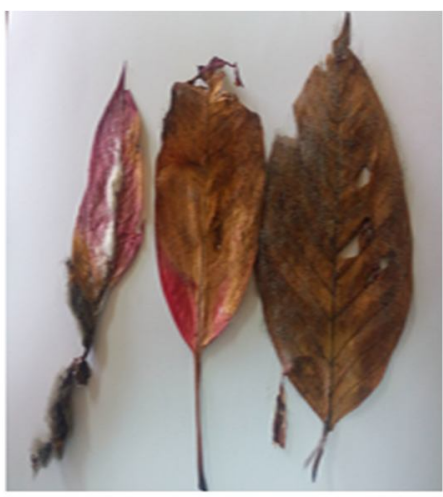

C

Fig. 1. Poinsettia (Euphorbia pulcherrima) leaves naturally infected by Botrytis blight (B \& C). Control $(A)$.

\section{Effect of ultrasonication on nanoemulsion droplet size:}

The effect of ultrasonication on the droplet size of essential oils of citronella and lemongrass nanoemulsions was determined. Figs. (2\&4) show the stable essential oil nanoemulsions prepared by ultrasonication method for $30 \mathrm{~min}$. at $700 \mathrm{~W}$ after 3 months of storage under room temperature. Tween 80 was used as surfactant for its high HLB value that favors formulation of oil-in-water emulsion. Also, small molecule surfactant like Tween 80 gets rapidly adsorbed onto emulsion droplet surface and hence they are more effective in decreasing droplet diameter than polymeric surfactants (Ghosh et al., 2014). Citronella nanoemulsion droplets were tiny (around $79.8 \mathrm{~nm}$ ). Mean droplet diameter of the nanoemulsion was calculated to be $66.29 \mathrm{~nm}$ with poly dispersity index (PDI) of 0.183 (Fig. 2). Lemongrass nanoemulsion droplets were tiny (around $90.6 \mathrm{~nm}$ ). Mean droplet diameter of the nanoemulsion was calculated to be $51.44 \mathrm{~nm}$ with poly dispersity index (PDI) of 0.227 (Fig.4) (Sampathi et al., 2015).

\section{Transmission electron microscopy (TEM):}

Transmission electron microscopy characterization of citronella and lemongrass essential oil nanoemulsions gives the actual size and shape; the droplets in the nanoemulsion appear dark. The TEM micrograph showed that the essential oils nanoemulsions were spherical in shape and moderately mono or di-dispersed. Citronella nanoemulsion droplets was in the range of $39-95.2 \mathrm{~nm}$ (Fig.3). Lemongrass 
nanoemulsion droplets was in the range of 29 - $99.71 \mathrm{~nm}$ (Fig.5). The droplet size was correlated well with the results obtained from droplet size analysis using the dynamic light scattering (Abd-Elsalam and Khokhlov, 2015).

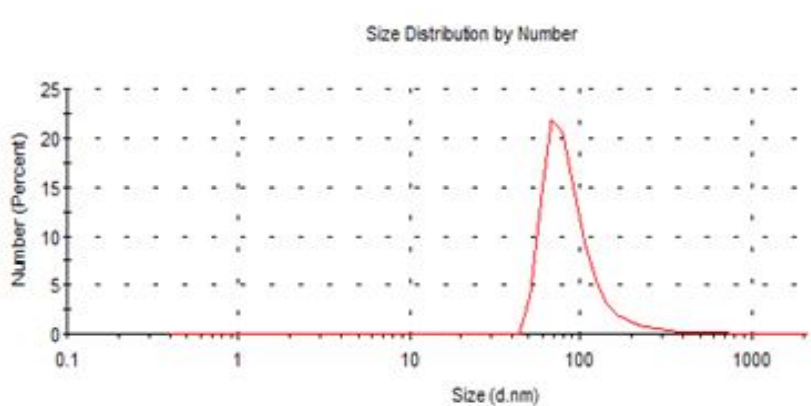

Fig. 2

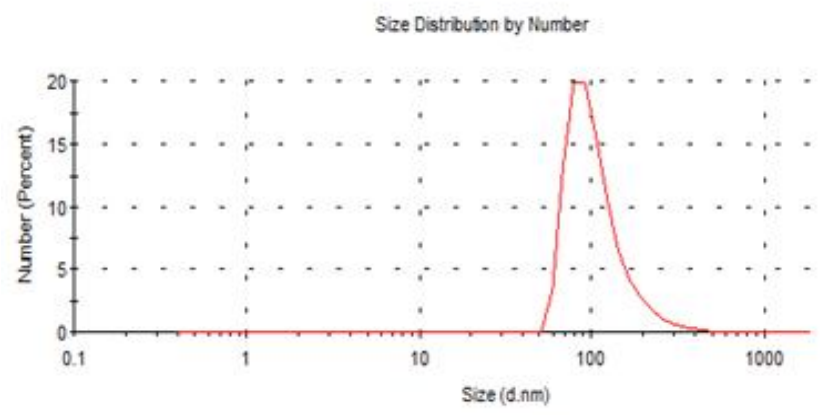

Fig. 4

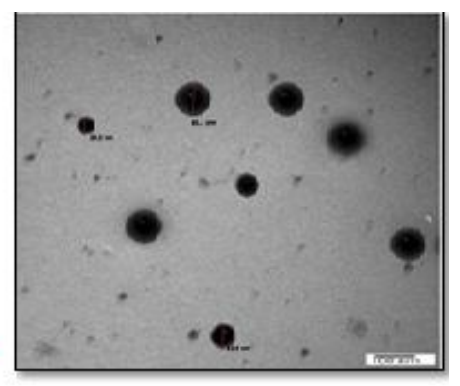

Fig. 3

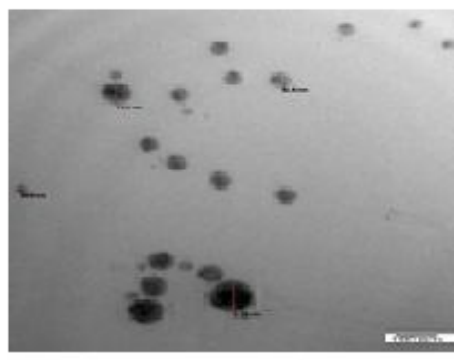

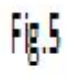

Fig. 2: Effect of ultrasonication on particle size of citronella essential oil nanoemulsion prepared by ultrasonication method for $30 \mathrm{~min}$. (peak at $79.8 \mathrm{~nm}$ ) \& (PDI=0.436).

Fig. 3: Transmission electron microscopic image of citronella essential oil nanoemulsion prepared by ultrasonication method for $30 \mathrm{~min}$. (size ranging from $39 \mathrm{~nm}$ to $95.2 \mathrm{~nm}$ ).

Fig. 4: Effect of ultrasonication on particle size of lemongrass essential oil nanoemulsion prepared by ultrasonication method for $30 \mathrm{~min}$. (peak at $90.6 \mathrm{~nm}) \&(\mathrm{PDI}=0.227$ ).

Fig.5: Transmission electron microscopic image of lemongrass essential oil nanoemulsion prepared by ultrasonication method for $30 \mathrm{~min}$. (size ranging from $29 \mathrm{~nm}$ to 99.71 $\mathrm{nm})$.

\section{Chemical composition of essential oils and essential oil nanoemulsions}

Chemical composition of investigated essential oils and essential oil nanoemulsions analyzed by gas chromatography are presented in Table (1). Geranial (3,7-dimethylocta-2,6-dienal $\left.\left(\mathrm{C}_{10} \mathrm{H}_{16} \mathrm{O}\right)\right) \quad(42.66 \%)$ and Neral(3,7-dimethyl-2,6octadienal $\left.\left(\mathrm{C}_{10} \mathrm{H}_{16} \mathrm{O}\right)\right)(31.82 \%)$ were identified as major constituents of lemongrass essential oil. Citronellal(3,7-dimethyloct-6-en-1-al $\left.\left(\mathrm{C}_{10} \mathrm{H}_{18} \mathrm{O}\right)\right)(44.85 \%)$, linalool(3,7Dimethylocta-1,6-dien-3-ol $\left.\left(\mathrm{C}_{10} \mathrm{H}_{18} \mathrm{O}\right)\right)(8.66 \%)$ and Citronellol(3,7-Dimethyloct-6-en-1- 
$\left.\mathrm{Ol}\left(\mathrm{C}_{10} \mathrm{H}_{20} \mathrm{O}\right)\right)(8.09 \%)$ were identified as the major constituents of citronella essential oil.

Changes in the essential oil components were observed in the nanoemulsions compared with the corresponding original essential oils. Data presented in Table (1) show that main component content of lemongrass oil nanoemulsions Neral and Geranial (34.23\% and $44.91 \%$, respectively) were increased, Also, in citronella oil nanoemulsions was citronellal increased (51.57\%) compared with essential oil.

The components of essential oils include different groups of distinct biosynthetically origin. The main group is composed of terpenoids, phenylpropanoids, and short-chain aliphatic hydrocarbon derivatives, which are all characterized by low molecular weight. Terpenes are made from combinations of several 5- carbon-base (C5) units called isoprene and form structurally and functionally different classes. The biosynthesis of the terpenes consists of synthesis of the isopentenyl diphosphate (IPP) precursor, repetitive addition of IPPs to form the prenyldiphosphate precursor of the various classes of terpenes, modification of the allylic prenyldiphosphate by terpene specific synthetases to form the terpene skeleton, and, finally, secondary enzymatic modification (redox reaction) of the skeleton to attribute functional properties to the different terpenes (Bilia et al., 2014).

It is suggested that, may be there was a breakdown of ultrasonic chemical bonds during the manufacture of the nanoemulsion. Once again the atoms are redistributed through the donor atom, which carries a positive charge such as the hydrogen atom and the recipient atom with a negative charge such as the oxygen atom. The compounds are then formed within aromatic oils again but at different concentrations.

\section{Effect of essential oils emulsions and nanoemulsions on growth of Botrytis cinerea:}

Data in Table (2) and Fig. (6) indicated that increasing concentration of essential oil emulsions and nanoemulsions can be correlated with a decrease in linear fungal growth. Nanoemulsions of lemongrass and citronella oils completely inhibited growth of Botrytis cinerea at the 8000 ppm concentration. Nanoemulsions were always the most active against fungal growth at all concentrations. It was noted that the nanoemulsions had been working efficiently for six months as opposed to normal oil emulsions. The biggest difference between emulsion and nanoemulsion is in the size of the nanoemulsion particles. When the size of the oil particles becomes small, the stability of the emulsion were significantly improved (Anton and Vandamme, 2011).Nanoemulsions are kinetically stable up to more than 6-months kept at room 
temperature and are formed from a particular concentration of oil phase, surfactant and water, with no phase separation(Abd-Elsalam and Khokhlov, 2015).

Table 1. Chemical composition of essential oils (EO) and essential oil nanoemulsions (EONE).

\begin{tabular}{|l|c|c|c|c|}
\hline \multirow{2}{*}{ Components (\%) } & \multicolumn{2}{|c|}{$\begin{array}{c}\text { Lemongrass } \\
\text { (Cymbopogon citratus) }\end{array}$} & \multicolumn{2}{c|}{$\begin{array}{c}\text { Citronella } \\
\text { (Cymbopogon nardus) }\end{array}$} \\
\cline { 2 - 5 } & EO & EONE & EO & EONE \\
\hline a-pinene & - & - & 1.61 & 0.85 \\
\hline Myrcene & - & - & 0.61 & 1.19 \\
\hline P- cymene & - & - & 2.26 & - \\
\hline Limonene & 1.44 & 6.64 & 1.94 & 0.22 \\
\hline Linalool & 2.73 & 3.38 & 8.66 & 1.21 \\
\hline$\beta$-caryophyllene & - & - & 7.49 & 0.52 \\
\hline Geranyl acetate & 3.19 & 2.01 & 2.38 & 1.33 \\
\hline a-myrcene & 14.19 & 6.24 & - & - \\
\hline Neral & 31.82 & 34.23 & - & - \\
\hline Geranial & 42.66 & 44.91 & - & 7.67 \\
\hline Citronellol & - & - & 8.09 & 51.57 \\
\hline Citronellal & - & - & 44.85 & \\
\hline Essential oil (\%) & & 0.4 & & 0.6 \\
\hline
\end{tabular}

Table 2. Effect of citronella and lemongrass essential oil concentrations on mycelial growth of pathogenic fungus Botrytis cinerea.

\begin{tabular}{|c|c|c|c|c|c|c|c|}
\hline \multirow{2}{*}{$\begin{array}{l}\text { Test essential } \\
\text { oils }\end{array}$} & \multirow{2}{*}{ Type of treatment } & \multicolumn{5}{|c|}{ Linear growth $(\mathrm{cm})$ at concentration (ppm) } & \multirow{2}{*}{ Mean } \\
\hline & & 0.0 & 1000 & 2000 & 4000 & 8000 & \\
\hline \multirow{2}{*}{ Citronella } & Emulsion & 9.0 & 8.0 & 6.3 & 5.0 & 3.2 & 6.3 \\
\hline & Nanoemulsion & 9.0 & 7.2 & 5.7 & 3.1 & 0.0 & 5.0 \\
\hline \multicolumn{2}{|c|}{ Mean } & 9.0 & 7.6 & 6.0 & 4.1 & 1.6 & 5.7 \\
\hline \multirow{2}{*}{ Lemongrass } & Emulsion & 9.0 & 6.4 & 4.9 & 3.3 & 1.9 & 5.1 \\
\hline & Nanoemulsion & 9.0 & 2.7 & 2.1 & 1.4 & 0.0 & 3.0 \\
\hline \multicolumn{2}{|c|}{ Mean } & 9.0 & 4.6 & 3.5 & 2.4 & 1.0 & 4.1 \\
\hline \multicolumn{2}{|c|}{ Mean of emulsions } & 9.0 & 7.2 & 5.6 & 4.2 & 2.6 & 5.7 \\
\hline \multicolumn{2}{|c|}{ Mean of nanoemulsion } & 9.0 & 5.0 & 3.9 & 2.3 & 0.0 & 4.0 \\
\hline
\end{tabular}

L.S.D. at $5 \%$ : Essential oils $(A)=0.6$, Type of treatment $(B)=0.1$, Concentrations $(C)=0.4, A \times B=0.1$, $\mathrm{A} \times \mathrm{C}=0.9, \mathrm{~B} \times \mathrm{C}=0.01, \mathrm{~A} \times \mathrm{B} \times \mathrm{C}=0.02$ 


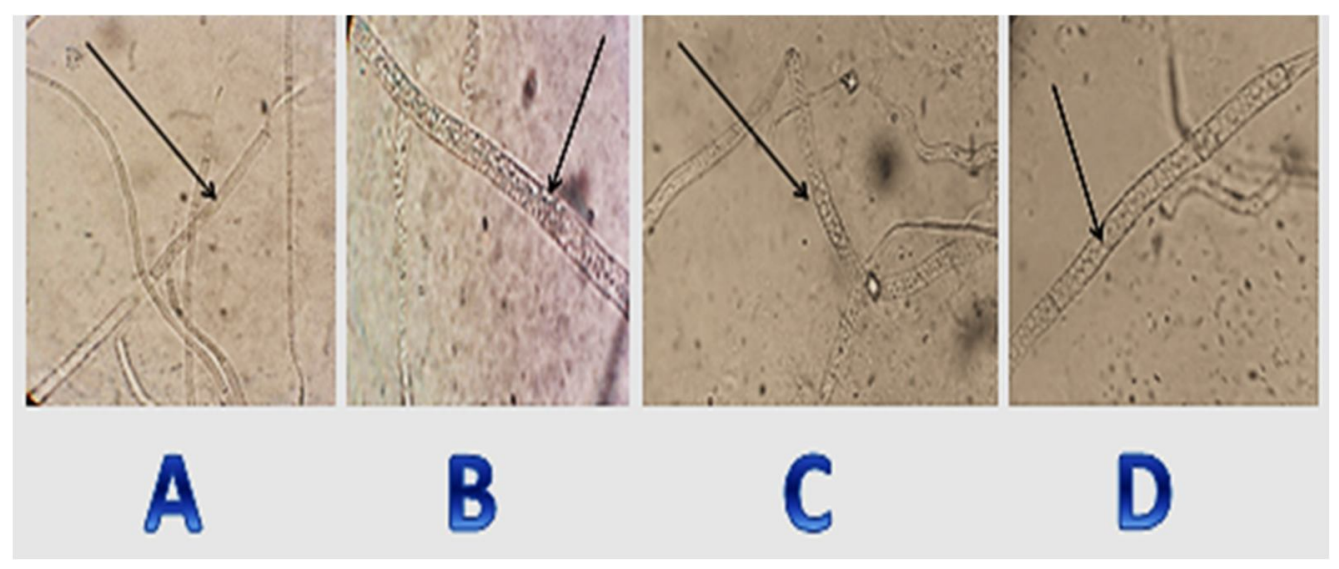

Fig. 6. Effect of essential oil nano emulsions on mycelial growth of pathogenic fungus Botrytis cinerea, showing granulation in the cytoplasm (C \& D) and bulge in the fungus mycelium (B). Oils tested are: lemongrass (B) and citronella (C\&D). Control (A).

Data in Table (3) indicate that the tested oils significantly inhibited sporulation of Botrytis cinerea. Data also show that the sporulation of Botrytis cinerea was completely prevented by lemongrass and citronella essential oil nanoemulsion at the $8000 \mathrm{ppm}$ concentration. Lemongrass and citronella essential oil nanoemulsions were always the most active against sporulation. The mode of action of the active substances in oils of medicinal and aromatic plants was interpreted by many scientists. Zambonelli et al., (1996) mentioned that these antifungal substances have high capabilities to damage structure and function of the enzymatic bioactivity. The fungal growth damages caused by essential oils might be due to their capabilities to penetrate into the fungal cells. They added that the antifungal activities might be due to increase in the permeability of the fungal cell as well as inhibition of the fungal detoxification enzymes. The medicinal oils are also capable to affect respiration of the fungal cell (oxygen uptake) and having toxic substances acting as anti-sporulation compounds (Inouye et al., 1988).

Data in Table (3) show also that sclerotial formation of Botrytis cinerea was significantly prevented by lemongrass and citronella essential oil nanoemulsions compared with that of the control. Sclerotial formation was also significantly affected by normal emulsions of lemongrass and citronella. This may be due to active phenolic constituents at different degrees in these oils. The activity of essential oils as anti-fungal was due to different concentrations of the phenolic fraction, especially citronellal, neral and/or geranial in oils of citronella or lemongrass (Muller-Riebaau et al., 1995). The biggest difference between emulsion and nanoemulsion is in the particle size. When the size of the oil particles become small, the stability of the emulsion significantly improved 
and the increase of efficiency of nanoemulsion may be due to the small size of its particles which confer additional properties (Anton and Vandamme, 2011).

Table 3. Effect of citronella and lemongrass essential oils at the concentration 4000\& $800 \mathrm{ppm}$ on sporulation of Botrytis cinerea after 7 days as well as sclerotial formation of Botrytis cinerea after 21 days incubation at $20 \pm 1^{\circ} \mathrm{C}$

\begin{tabular}{|c|c|c|c|c|c|}
\hline \multirow{3}{*}{$\begin{array}{c}\text { Test essential } \\
\text { oils }\end{array}$} & \multirow{4}{*}{ Type of treatment } & \multicolumn{4}{|c|}{ Botrytis cinerea } \\
\cline { 3 - 6 } & & \multicolumn{2}{|c|}{ No. of sclerotia } & \multicolumn{2}{c|}{$\begin{array}{c}\text { Mean sporulation } \\
\left(\times 10^{-3}\right)\end{array}$} \\
\cline { 3 - 6 } & & $\begin{array}{c}4000 \\
\mathrm{Ppm}\end{array}$ & $\begin{array}{c}8000 \\
\mathrm{ppm}\end{array}$ & $\begin{array}{c}4000 \\
\mathrm{Ppm}\end{array}$ & $\begin{array}{c}8000 \\
\text { Ppm }\end{array}$ \\
\cline { 3 - 6 } & & 33 & 21 & 125 & 105 \\
\hline \multirow{2}{*}{ Citronella } & Emulsion & 0 & 0 & 45 & 0 \\
\cline { 2 - 6 } & Nanoemulsion & 8 & 2 & 55 & 45 \\
\hline \multirow{2}{*}{ Lemongrass } & Emulsion & 0 & 0 & 20 & 0 \\
\cline { 2 - 6 } & Nanoemulsion & 46 & 46 & 185 & 185 \\
\hline Control & Without treatment & 3.6 & 2.0 & 27.1 & 21.4 \\
\hline L.S.D. at 5\% & - & & & & \\
\hline
\end{tabular}

\section{Effect of the tested oil treatments on severity percent of leaf blight caused} by $B$. cinerea:

In this experiment, poinsettia plants were sprayed with the two essential oils (Emulsion and Nanoemulsion) and fungicide of carbendazim 50\% WP, 24 hr. after or before inoculation by the fungus) to suppress the leaf blight disease. The disease severity was significantly reduced by the treatments compared with the untreated control. The lowest disease severity percentages, being 10.0 and $13.0 \%$ with nanoemulsion of lemongrass, before and after inoculation by the fungus, respectively. The positive effect on plants when treated with nano-emulsion before to fungal infection may be due to the increased activity of enzymes such as peroxidase and polyphenols oxidase, leading to effective management (Hassanin et al., 2017). Meanwhile emulsion of citronella recorded the highest disease severity, being 23.33 and $34.44 \%$. The untreated inoculated control recorded $45.55 \%$ (Table 4).However, the positive effect on plants when treated with nanoemulsion after fungal infection may be due to anti-fungal effect due to the presence of active substances in essential oils such as citronellal, neral or geranial. We noted an improvement in plants treated with nanoemulsions compared with normal emulsions and fungicides used, possibly because of the small size of the droplets of nanoemulsions and their rapid interaction with fungi and plant cells, as well as improvement of the essential active chemicals of nanoemulsion (Anton and Vandamme, 2011). 
Table 4. The effect of the tested oil treatments on severity percent of poinsettia leaf blight caused by $B$. cinerea

\begin{tabular}{|c|l|c|c|}
\hline \multicolumn{2}{|c|}{ Treatment } & \multicolumn{2}{c|}{ Disease severity\% } \\
\cline { 3 - 4 } \multicolumn{2}{|c|}{} & $\begin{array}{c}\text { Spraying with treatment } \\
\text { after inoculation by the } \\
\text { fungus(24 hr.) }\end{array}$ & $\begin{array}{c}\text { Spraying with treatment } \\
\text { before inoculation by } \\
\text { the fungus (24 hr.) }\end{array}$ \\
\hline \multirow{2}{*}{ Citronella oil } & Emulsion & 34.4 & 23.3 \\
\cline { 2 - 4 } & Nanoemulsion & 19.2 & 13.0 \\
\hline \multirow{2}{*}{ Lemongrass oil } & Emulsion & 24.4 & 15.9 \\
\cline { 2 - 4 } & Nanoemulsion & 13.0 & 10.0 \\
\hline Carbendazim 50\% WP (fungicide) & 18.2 & 14.5 \\
\hline \multicolumn{2}{|l|}{ Control (without any treatment) } & 45.6 & 45.6 \\
\hline L.S.D.at 5\% & 2.5 & 4.6 \\
\hline
\end{tabular}

\section{REFERENCES}

1. Abd-Elsalam, K. A. and A. R. Khokhlov. 2015. Eugenol oil nanoemulsion: antifungal activity against Fusarium oxysporum $f$. sp. vasinfectum and phytotoxicity on cotton seeds. Appl. Nanosci., 5: 255-265.

2. Adebayo, O., T. Dang, A. Belanger andS. Khanizadeh. 2013. Antifungal studies of selected essential oils and a commercial formulation against Botrytis cinerea. J. Food Res., 2(1), 217-226.

3. Al-Shahrani, M. H., M. Mahfoud, R. Anvarbatcha, M.d. T. Athar and A. Al-Asmari 2017. Evaluation of antifungal activity and cytotoxicity of Thymus vulgaris essential oil. Pharmacogn.Common., 7(1) : 34-40.

4. Anonymous, 2011. Poinsettia (Euphorbia pulcherrima). http://www.buyshrubszone.com/si/euphorbia/poinsettia_euphorbia_pulcherrima. html.

5. Anton, N. and T. F. Vandamme. 2011. Nano-emulsions and micro-emulsions: clarifications of the critical differences. Pharm. Res., 28 : 978-985.

6. Bilia, A.R., C. Guccione, B. Isacchi, C. Righeschi, F. Firenzuoli and M.C. Bergonzi 2014. Essential oils loaded in nanosystems: a developing strategy for a successful therapeutic approach. Evidence-Based Complementary and Alternative Medicine. Article ID 651593, 14 pages. (http://dx.doi.Org/10.1155/2014/651593).

7. Brent, K. J. and D.W. Hollomon. 1998. Fungicide resistance: the assessment of risk. FRAC. Global Crop Prot. Fed., Brussels, Monograph, 2: 1-48.

8. Burt, S. 2004. Essential oils: their antibacterial properties and potential applications in foods - a review. Int. J. Food Microbiol., 94: 223-253.

9. Dijst, G. 1988. Formation of sclerotia by Rhizoctonia solani on artificial media and potato tubers. Netherlands Journal of Plant Pathology, 94: 233-242. 
10. Ghosh, V., A. Mukherjee and N. Chandrasekaran 2014. Eugenol-loaded antimicrobial nanoemulsion preserves fruit juice against, microbial spoilage. Colloids Surf. B.Biointerfaces, 114:392-397.

11. Ghotbi, R. S., M. Khatibzadeh and S. Kordbacheh. 2014. Preparation of neem seed oil nanoemulsion. Proceedings of the 5th International Conference on nanotechnology: Fundamentals and Applications Prague, Czech Republic, August 11-13, Paper No. 150-1.

12. Hamad, A., A. Nuritasari and D. Hartanti. 2017. Chemical composition and antimicrobial study of essential oil of lemongrass (Cymbopogon citratus). Der Pharmacia Lettre, 9 (5):109-116.

13. Hammer, K.A., C.F. Carson and T.V. Riley. 2003. Antifungal activity of the components of Melaleuca alternifolia (tea tree) oil. J. Appl. Microbiol., 95: 853860.

14. Hassanin, M. M. H., A. E. A. Halawa and A. A. M. Ali. 2017. Evaluation of the activity of thyme essential oil nanoemulsion against Sclerotinia rot of fennel. Egypt. J. Agric. Res., 95(3): 1037-1050.

15. Inouye, S., M. Watanable, Y. Nishiyama, K. Takeo, M. Akao and H. Yamaguchi 1988. Antisporulation and respiration effects of essential oils on filamentous fungi. Mycoses, 41:403-410.

16. Larson, R.A., J.W. Love and D.L. Strider. 1978. Commercial poinsettia production.N.C. Agr. Ext. Ser. Ag-108.

17. Margery Daughtrey L. and A.R. Chase. 2016. Diseases of Poinsettia. R.J. McGovern, W.H. Elmer (eds.), Handbook of Florist's Crops Diseases, 1:51.

18. Margery Daughtrey L., R.L. Wick and J.L. Peterson. 2000. Botrytis Blight of flowering potted plants. https://www. Plant management network. org/pub/management/botrytis/.

19. Mary Hausbeck K., B.R. Harlan. 2011. Evaluation of new products for control of Botrytis on poinsettia. Plant Disease Management Reports 6:OT007.

20. Muller-Riebaau, F., B. Berger and O. Yegan. 1995. Chemical composition and fungitoxic properties to phyto-pathogenic fungi of essential oils of selected aromatic plants growing wild in Turkey. Agric. And Food Chem., 43(8): 2262-2266 (c.f. Rev. Pl. Pathol., 75(2): 91, 1996).

21. Palmucci, H. E. and P. E. Grijalba. 2005. Leaf Spot and Stem Blight Caused by Botrytis cinerea on Poinsettia in Argentina.Plant Disease, 89(12):1359-1359.

22. Pauli, A. 2001. Antimicrobial properties of essential oil constituents. Int. J. Aromatherapy, $11: 126-133$. 
23. Pepeljnjak, S., I. Kosalec,Z. Kalodera and D.Kuštrak. 2003. Natural antimycotics from Croatian plants. In Plant-Derived Antimycotics ed. Rai, M. and Mares, D. pp. 49-81. Binghampton: The Haworth Press.

24. Pritchard P.M., M.K. Hausbeck and R. D. Heins. 1996. The influence of diurnal temperatures on postharvest susceptibility of poinsettia to Botrytis cinerea.Plant. Dis., 80:1011-1014.

25. Saloko, S., P. Darmadji, B. Setiaji, Y. Pranoto and A.K. Anal. (2013). Encapsulation of coconut shell liquid smoke in chitosan-maltodextrin based nanoparticles. Int. Food Res. J., $20: 1269-1276$.

26. Sampathi, S., S.K. Mankala, W. Ankar and J.S. Dodoala. 2015. Nanoemulsion based hydrogel of itraconazole for transdermal drug delivery. Journal of Scientific \& Industrial Research, 74:88- 92.

27. Snendecor, G.W. and Cochran, W.G. 1989. Statistical Methods. 8th ed. Iowa State Univ. Press, Ames, Iowa, USA.

28. Zambonelli, A., A. Bianchi and A. Albasini. 1996. Effect of essential oils on phytopathogenic fungi in vitro. Phytopathology, 86: 491-494. 


\title{
كفاءة مستحلب النانو للزيوت الطيارة كمادة مضادة لمرض لفحة الأوراق المتسبية
}

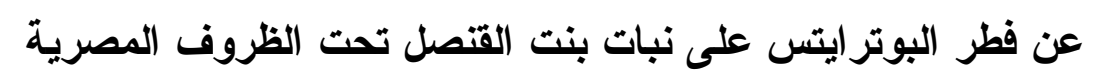

\author{
محمود محمد حساتين حساتين 1 ، نجلاء طلعت محمد1 ، محمد عبد القوي عبد السيد2 \\ 1 - معهد بحوث أمر اض النباتات، مركز البحوث الزراعية، مصر

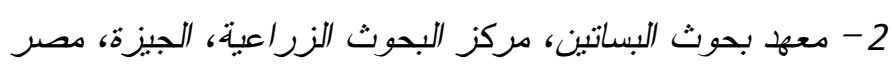

لوحظت لفحة البوتز ايتس في مصر (نوفمبر / Euphorbia 2016) على نباتات بنت القنصل

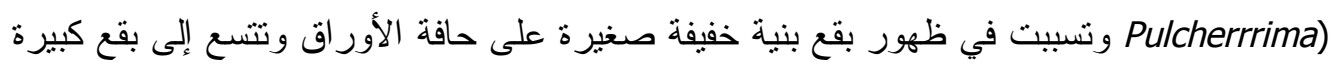

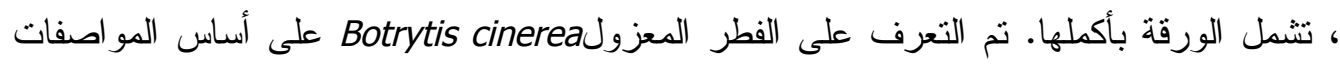
المزرعية والمورفولوجية للنمو الفطري. ولقد سببت العدوى الصناعية للنباتات ظهور أعر اض الإصابة باللفحة في الصوبة. تم تحديد تأثثر ultrasonication على حجم جسيمات المستحلب النانومنزي لكل

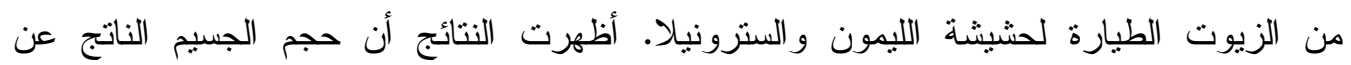
ultrasonication لمدة 30 دقيقة كان حوالي 90,6 و 79,8 نانومتر على الترنيب، وكثنت دراسة

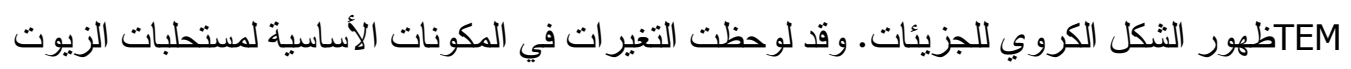
العطرية النانومنرية مقارنة بالمستحلبات العادية لنفس الزيوت. و عندما يصبح حجم جسيمات الزيت

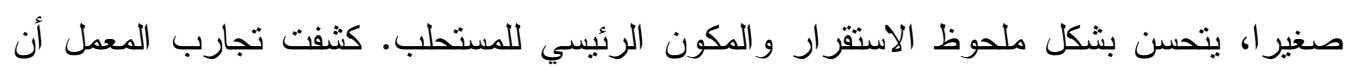
مستحلبات النانو بنركيز ات مختلفة (1000 - 8000 جز ء في المليون) قادرة على التأثير سلبا على فئى

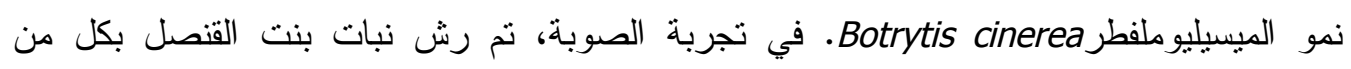

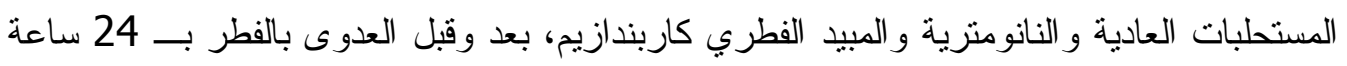

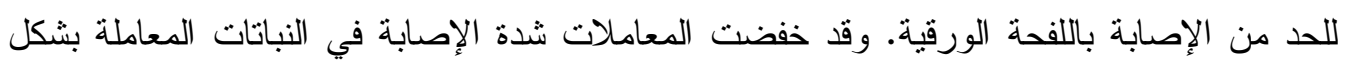

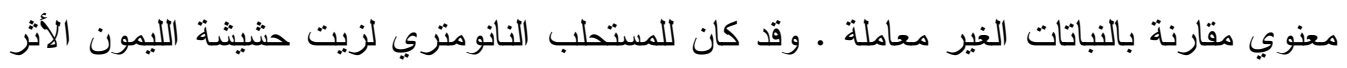

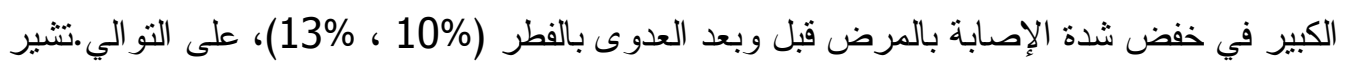

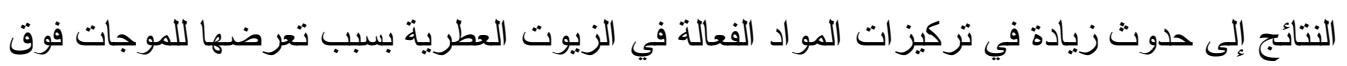

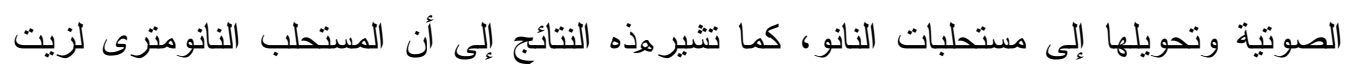

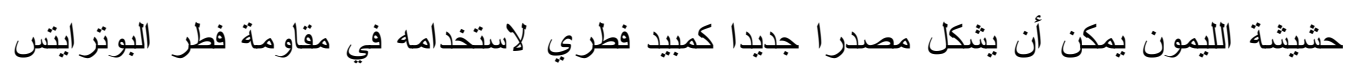


